\title{
Study of serum C-reactive protein concentration in cardiac failure
}

\author{
Maurice Pye, Alan P Rae, Stuart M Cobbe
}

\begin{abstract}
The serum concentration of $\mathbf{C}$-reactive protein was prospectively assessed in 37 patients with various degrees of heart failure. The serum concentration of $C$ reactive protein was higher than normal in $26(70 \%)$ patients. The concentration was directly related to the severity of heart failure and the stage of decompensation. Hepatic cell damage is the most likely stimulus to cytokine production and hence release of C-reactive protein in heart failure. Heart failure is an additional cause of raised serum concentration of C-reactive protein but the pathological importance of this feature is not yet known.
\end{abstract}

C-reactive protein is synthesised in the liver and is an acute phase reactive protein. Its concentration in serum rises rapidly in patients in response to tissue injury, infection, or inflammation. ${ }^{1}$ When the stimulus resolves, for example, with effective antimicrobial treatment, the concentration falls rapidly. ${ }^{2}$ Measurements of C-reactive protein were useful in diagnosing and assessing the extent of damage in myocardial infarction..$^{3-5}$ More recently it has been proposed as a marker of successful thrombolysis and early reperfusion in myocardial infarction. ${ }^{6}$ It has provided a complementary diagnostic test in infective endocarditis and has been used as an index of response to treatment in this condition. ${ }^{7}$ We noticed that patients who had evidence of heart failure in the absence of acute myocardial infarction, systemic infection, or inflammatory disease had raised serum concentra- tions of C-reactive protein. The acute phase protein response has not been studied in heart failure. We prospectively studied serum concentrations of C-reactive protein in patients with varying degrees of heart failure.

\section{Patients and methods}

PATIENTS

We studied 37 patients admitted to hospital for investigation and treatment of cardiac failure (table 1). Heart failure was caused by ischaemic heart disease in 20 , valve disease in 10 , idiopathic dilated cardiomyopathy in six, and systemic hypertension in one. We also measured the serum concentrations of C-reactive protein in 15 control patients admitted for routine coronary arteriography with no clinical evidence or history of heart failure and normal left and right ventricular function. Venous blood samples were obtained from patients on admission and every $24-48$ hours during their hospital stay. The control group were sampled before and 24 hours after coronary arteriography.

\section{DEFINITIONS}

The diagnosis of cardiac failure was based on the following:

(a) Left heart failure-sinus tachycardia $>90 /$ min with a third heart sound and clinical or radiological evidence of a raised pulmonary venous pressure.

(b) Right heart failure-raised jugular venous pressure with or without congestive hepatomegaly and with or without peripheral oedema.

This was supported by objective evidence of left or right ventricular dysfunction with

Accepted for publication 15 December 1989

Table 1 Clinical details and peak concentrations of serum $C$-reactive protein in 37 patients in heart failure

\begin{tabular}{|c|c|c|c|c|c|c|c|c|c|c|c|c|c|c|c|c|c|}
\hline $\begin{array}{l}\text { Patient } \\
\text { no }\end{array}$ & $\begin{array}{l}\text { Age } \\
(y r)\end{array}$ & Sex & Diagnosis & Cause & Stage & Severity & $\begin{array}{l}\text { LVEF } \\
(\%)\end{array}$ & $\begin{array}{l}\text { Peak } \\
\text { CRP } \\
(\mathrm{mg} / \mathrm{ml})\end{array}$ & $\begin{array}{l}\text { Patient } \\
\text { no }\end{array}$ & $\begin{array}{l}\text { Age } \\
(y r)\end{array}$ & Sex & Diagnosis & Cause & Stage & Severity & $\begin{array}{l}\text { LVEF } \\
(\%)\end{array}$ & $\begin{array}{l}\text { Peak } \\
C R P \\
(\mathrm{mg} / \mathrm{ml})\end{array}$ \\
\hline $\begin{array}{r}1 \\
2 \\
3 \\
4 \\
5 \\
6 \\
7 \\
8 \\
9 \\
10 \\
11 \\
12 \\
13 \\
14 \\
15 \\
16 \\
17 \\
18 \\
19\end{array}$ & $\begin{array}{l}56 \\
57 \\
63 \\
69 \\
63 \\
68 \\
61 \\
63 \\
55 \\
63 \\
55 \\
53 \\
52 \\
45 \\
52 \\
50 \\
62 \\
61 \\
60\end{array}$ & 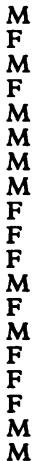 & $\begin{array}{l}\text { L+RHF } \\
\text { L }+ \text { RHF } \\
\text { L }+ \text { RHF } \\
\text { L+RHF } \\
\text { LHF } \\
\text { L+RHF } \\
\text { LHF } \\
\text { RHF } \\
\text { L+RHF } \\
\text { RHF } \\
\text { RHF } \\
\text { LHF } \\
\text { L+RHF } \\
\text { L+RHF } \\
\text { L + RHF } \\
\text { L + RHF } \\
\text { RHF } \\
\text { L+RHF } \\
\text { LHF }\end{array}$ & $\begin{array}{l}\text { IHD } \\
\text { IHD } \\
\text { IHD } \\
\text { DCM } \\
\text { IHD } \\
\text { Valve* } \\
\text { IHD } \\
\text { Valve } \\
\text { DCM } \\
\text { Valve } \\
\text { Valve } \\
\text { IHD } \\
\text { DCM } \\
\text { IHD } \\
\text { IHD } \\
\text { Valve } \\
\text { Valve } \\
\text { IHD } \\
\text { IHD }\end{array}$ & $\begin{array}{l}\text { Acute } \\
\text { Acute } \\
\text { Acute } \\
\text { Acute } \\
\text { Chronic } \\
\text { Acute } \\
\text { Acute } \\
\text { Chronic } \\
\text { Acute } \\
\text { Chronic } \\
\text { Chronic } \\
\text { Acute } \\
\text { Acute } \\
\text { Chronic } \\
\text { Acute } \\
\text { Acute } \\
\text { Acute } \\
\text { Acute } \\
\text { Chronic }\end{array}$ & $\begin{array}{l}\text { Severe } \\
\text { Severe } \\
\text { Severe } \\
\text { Severe } \\
\text { Severe } \\
\text { Severe } \\
\text { Severe } \\
\text { Severe } \\
\text { Severe } \\
\text { Mild } \\
\text { Mild } \\
\text { Severe } \\
\text { Severe } \\
\text { Moderate } \\
\text { Severe } \\
\text { Severe } \\
\text { Moderate } \\
\text { Severe } \\
\text { Severe }\end{array}$ & $\begin{array}{l}15 \\
17 \\
12 \\
20 \\
15 \\
30 \\
15 \\
35 \\
12 \\
40 \\
35 \\
20 \\
15 \\
20 \\
20 \\
30 \\
33 \\
29 \\
15\end{array}$ & $\begin{array}{r}51 \\
72 \\
90 \\
16 \\
21 \\
67 \\
71 \\
19 \\
20 \\
<10 \\
<10 \\
120 \\
47 \\
87 \\
135 \\
22 \\
27 \\
<10 \\
<10\end{array}$ & $\begin{array}{l}20 \\
21 \\
22 \\
23 \\
24 \\
25 \\
26 \\
27 \\
28 \\
29 \\
30 \\
31 \\
32 \\
33 \\
34 \\
35 \\
36 \\
37\end{array}$ & $\begin{array}{l}63 \\
58 \\
62 \\
60 \\
62 \\
55 \\
49 \\
59 \\
57 \\
63 \\
62 \\
67 \\
63 \\
64 \\
57 \\
65 \\
63 \\
68\end{array}$ & $\begin{array}{l}\mathbf{M} \\
\mathbf{F} \\
\mathbf{M} \\
\mathbf{M} \\
\mathbf{M} \\
\mathbf{M} \\
\mathbf{M} \\
\mathbf{F} \\
\mathbf{M} \\
\mathbf{F} \\
\mathbf{M} \\
\mathbf{F} \\
\mathbf{M} \\
\mathbf{F} \\
\mathbf{M} \\
\mathbf{F} \\
\mathbf{M} \\
\mathbf{F}\end{array}$ & $\begin{array}{l}\text { LHF } \\
\text { LHF } \\
\text { L+RHF } \\
\text { LHF } \\
\text { RHF } \\
\text { L +RHF } \\
\text { L+RHF } \\
\text { L+RHF } \\
\text { RHF } \\
\text { L+RHF } \\
\text { L + RHF } \\
\text { L+RHF } \\
\text { L+RHF } \\
\text { LHF } \\
\text { LHF } \\
\text { LHF } \\
\text { L+RHF } \\
\text { L + RHF }\end{array}$ & $\begin{array}{l}\text { Hypertension } \\
\text { Valve } \\
\text { IHD } \\
\text { IHD } \\
\text { Valve } \\
\text { IHD } \\
\text { IHD } \\
\text { Valve } \\
\text { Valve } \\
\text { DCM } \\
\text { IHD } \\
\text { DCM } \\
\text { IHD } \\
\text { IHD } \\
\text { IHD } \\
\text { DCM } \\
\text { IHD } \\
\text { IHD }\end{array}$ & $\begin{array}{l}\text { Chronic } \\
\text { Chronic } \\
\text { Acute } \\
\text { Chronic } \\
\text { Chronic } \\
\text { Chronic } \\
\text { Acute } \\
\text { Chronic } \\
\text { Chronic } \\
\text { Acute } \\
\text { Acute } \\
\text { Acute } \\
\text { Acute } \\
\text { Chronic } \\
\text { Chronic } \\
\text { Acute } \\
\text { Chronic } \\
\text { Chronic }\end{array}$ & $\begin{array}{l}\text { Severe } \\
\text { Moderate } \\
\text { Severe } \\
\text { Moderate } \\
\text { Moderate } \\
\text { Mild } \\
\text { Severe } \\
\text { Mild } \\
\text { Severe } \\
\text { Severe } \\
\text { Severe } \\
\text { Severe } \\
\text { Severe } \\
\text { Severe } \\
\text { Mild } \\
\text { Severe } \\
\text { Mild } \\
\text { Mild }\end{array}$ & $\begin{array}{l}35 \\
30 \\
20 \\
24 \\
35 \\
16 \\
24 \\
28 \\
23 \\
20 \\
14 \\
19 \\
15 \\
29 \\
30 \\
20 \\
32 \\
28\end{array}$ & $\begin{array}{r}<10 \\
16 \\
51 \\
<10 \\
36 \\
29 \\
38 \\
<10 \\
<10 \\
40 \\
75 \\
34 \\
83 \\
15 \\
<10 \\
<10 \\
20 \\
<10\end{array}$ \\
\hline
\end{tabular}

^Aortic and/or mitral disease.

DCM, dilated cardiomyopathy; IHD, ischaemic heart disease; LHF, left heart failure; RHF, right heart failure; LVEF, left ventricular ejection fraction; CRP, C reactive protein. 
Table 2 Classification of degree of cardiac failure

\begin{tabular}{|c|c|c|c|}
\hline Category & $C X R$ & $\begin{array}{l}\text { Mean PCWP } \\
(\text { mm } H g)\end{array}$ & $\begin{array}{l}\text { P Peripheral } \\
\text { perfusion }\end{array}$ \\
\hline $\begin{array}{l}\text { Mild } \\
\text { Moderate } \\
\text { Severe }\end{array}$ & $\begin{array}{l}\text { Vascular redistribution } \\
\text { Interstitial oedema } \\
\text { Alveolar oedema }\end{array}$ & $\begin{array}{l}13-17 \\
18-23 \\
>23\end{array}$ & $\begin{array}{l}\text { Normal } \\
\text { Normal } \\
\text { Reduced }\end{array}$ \\
\hline
\end{tabular}

CXR, appearance on chest $x$ ray; PCWP, pulmonary capillary wedge pressure.

either echocardiography, radionuclide scanning, or invasive haemodynamic measurement of pulmonary capillary wedge pressure. Patients were classed as having mild, moderate, or severe heart failure on the basis of peripheral perfusion and radiologically estimated or directly measured pulmonary capillary wedge pressure (table 2 ). Poor peripheral perfusion was based on finding two or more of the following criteria: (a) skin vasoconstriction, (b) hypotension (systolic blood pressure $<90 \mathrm{~mm} \mathrm{Hg}$ by cuff method), and $(c)$ raised blood urea in the absence of any other identifiable cause. A few patients fitted into more than one class of severity and were placed in the highest category attained on the basis of gry criterion. Heart failure was defined as acute if the onset or decompensation has occurred within one month and as chronic if it had occurred more than one month before presentation. We did not distinguish between acute or acute on chronic heart failure in our analysis.

\section{EXCLUSION CRITERIA}

We excluded patients with clinical or laboratory evidence of systemic infection or inflammatory or neoplastic disease. We monitored cardiac enzymes and electrocardiograms to exclude any patient who had had a recent ( $<7$ days) myocardial infarction.

\section{MEASUREMENT OF C-REACTIVE PROTEIN}

We measured serum concentrations of C-reactive protein by fluorescence polarimetry. The intra-assay coefficient of variation was $<5 \%$ and a concentration of $<10 \mu \mathrm{g} / \mathrm{ml}$ was regarded as normal. ${ }^{8}$

\section{STATISTICAL ANALYSIS}

Groups were compared by the unpaired $t$ test, and a $\mathrm{p}$ value $<0.05$ was regarded as significant.

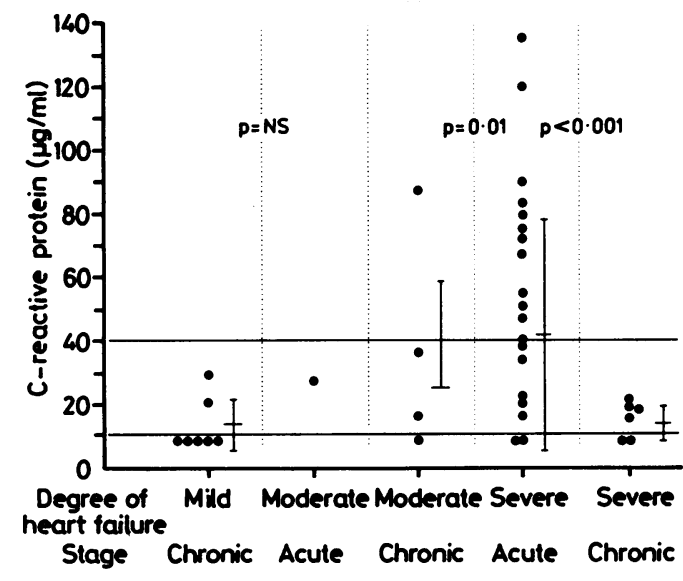

Figure 1 Comparison between stage and degree of heart failure and serum concentration of $C$-reactive protein.

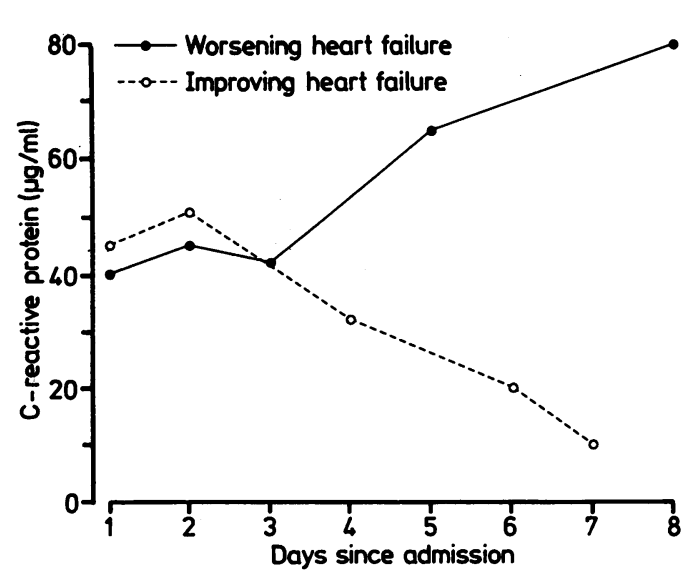

Figure 2 Serial concentrations of serum $C$-reactive protein from two patients with left ventricular failure who responded differently to treatment.

\section{Results}

Twenty six $(70 \%)$ of the 37 patients had a raised serum concentration of C-reactive protein (table 1). None of the 15 control patients had a raised serum concentration. In $14(38 \%)$ patients it was slightly raised (10-40 $\mu \mathrm{g} / \mathrm{ml})$ and in 12 patients $(32 \%)$ it was considerably raised $(>40 \mu \mathrm{g} / \mathrm{ml})$. Figure 1 shows the relation between the degree of heart failure and the serum concentration of C-reactive protein. All but one of the 12 patients with a C-reactive protein concentration $>40$ $\mu \mathrm{g} / \mathrm{ml}$ had severe heart failure and acute rather than chronic heart failure. Six patients had isolated right ventricular failure caused by valve disease or fixed pulmonary hypertension and all had serum concentrations of C-reactive protein $<40 \mu \mathrm{g} / \mathrm{ml}$. When acute cardiac failure was stabilised or improved with treatment the serum concentration of C-reactive protein gradually returned to normal values. Conversely in patients who deteriorated the serum concentrations of C-reactive protein tended to remain high (fig 2).

Serum concentrations of aspartate and alanine transaminases were raised in $33 \%$ and $23 \%$ of the patients respectively. There was no direct correlation between the serum concentration of C-reactive protein and transaminase concentrations, which were more commonly raised in acute severe cardiac failure. The concentration of serum $\gamma$ glutamyl transpeptidase too was more often $(40 \%)$ raised in these patients but once again there was no close correlation with the serum concentration of C-reactive protein.

\section{Discussion}

We found that serum concentrations of Creactive protein were higher than normal in $70 \%$ of patients with cardiac failure although in about half the increase was quite small $(<40 \mu \mathrm{g} / \mathrm{ml})$. There was a significant difference between the serum concentrations of C-reactive protein in those with acute and chronic severe heart failure (fig 1). All but one patient with a considerably increased serum concentration of C-reactive protein ( $>40 \mu \mathrm{g}$ ) $\mathrm{ml}$ ) had severe cardiac failure. The tendency for concentrations of $\mathrm{C}$-reactive protein to fall 
with successful treatment (fig 2) also suggests that the severity of cardiac failure directly influences serum concentrations of $\mathrm{C}$-reactive protein. In keeping with these findings de Beer et al noted that in eight patients whose recovery after a myocardial infarction was complicated by cardiac insufficiency or low output state, the serum concentration of Creactive protein did not return to normal as it did in uncomplicated myocardial infarction. ${ }^{4}$ Subgroup analysis of patients with predominantly forward or backward heart failure showed no significant difference in the serum concentrations of C-reactive protein.

C-reactive protein is synthesised by hepatocytes and normally only a trace is present in the plasma. It is part of the protein response in the acute phase to tissue injury along with other plasma proteins such as antitrypsin, caeruloplasmin, and fibrinogen. The rate of synthesis and secretion of C-reactive protein increases within hours of acute injury or the onset of inflammation. ${ }^{910}$ This is probably under the influence of several hormonal mediators called cytokines-for example IL6 or hepatocyte stimulating factor. We think hepatic necrosis is the most likely site of tissue damage that leads to macrophage activation, cytokine production, and release of C-reactive protein in patients with heart failure. Hepatic centrilobular necrosis has been described in isolated left and right heart failure and congestive heart failure as a result of reduced cardiac output, hypoperfusion, hypoxia, and venous congestion. ${ }^{11-13}$ This necrosis is often accompanied by alterations in other indices of liver damage or function particularly hepatic release of transaminase. ${ }^{111314}$ In this present study serum concentrations of alanine and aspartate transaminase were raised in about a third of patients and the concentration of $\gamma$-glutamyl transpeptidase was more often raised. The synthesis and release of $C$ reactive protein is perhaps a more sensitive indicator of hepatic damage in this situation than either the concentrations of transaminase or transpeptidase. Alternatively, there may be additional sites of tissue damage in cardiac failure, for example kidney, brain, or skeletal muscle. Other possible causes of release of $\mathrm{C}$ reactive protein in this clinical setting include occult infection or pulmonary thromboembolism. There was no clinical evidence of these complications and all patients with a significant fever-that is $>37.0^{\circ} \mathrm{C}$ on two occasions-or clinical evidence of any infec- tion were excluded from the study even if blood, secretion, or tissue cultures were negative. Ventilation-perfusion lung scans were performed in nine patients and all were negative. In addition, 15 patients were well controlled on long term treatment with anticoagulants.

The serum concentration of C-reactive protein provides a simple screening test for the presence of organic disease and is widely used. Because an increase in C-reactive protein is a non-specific response to tissue injury it must be interpreted in the light of clinical information. This study shows a further condition in which the serum concentration of C-reactive protein is raised. It is important to be aware of this phenomenon when measurements of $\mathrm{C}$-reactive protein are interpreted-for example in patients with leaking prosthetic cardiac valves, heart failure, and suspected infective endocarditis. It also raises the question whether acute phase reactive proteins or cytokines are involved in the pathogenesis of cardiac failure or are simply markers of tissue injury.

1 Pepys MB. C-reactive protein fifty years on. Lancet 1981 ;i: 653-6.

2 Kushner J, Volanakis JE, Gewurz H. C-reactive protein an the plasma protein response to tissue injury. Ann NY Acad Sci 1982;389:96.

3 Levinger EL, Levy H, Elster SK. Study of C-reactive protein in the sera of patients with acute myocardial infarction. Ann Intern Med 1957;46:68-78.

4 De Beer FC, Hind CRK, Fox KM, Allan RM, Maseri A, Pepys MB. Measurement of serum C-reactive protein concentration in myocardial ischaemia and infarction. Br Heart J 1982;47:239-43.

5 Pietila K, Harmoinen A, Poyhonen L, Ruosteenoja R. Creactive protein in subendocardial and transmura myocardial infarcts. Clin Chem 1986;32:1596-7.

6 Pietilä K, Harmoinen A, Pöyhönen L, Koskinen M, Heikkilä J, Ruosteenoja R. Intravenous streptokinase treatment and serum C-reactive protein in patients with acute myocardial infarction. Br Heart $J$ 1988;58:225-9.

7 McCartney AC, Orange GV, Pringle SD, Wills G, Reece IJ. Serum $C$ reactive protein in infective endocarditis. $J$ Clin Serum C reactive prot

8 Shine B, de Beer FC, Pepys MB. Solid phase radioimmunosess for $\mathrm{C}$ reactive protein Clin Chim Acta 1981;117:13-23.

9 Kushner I, Feldman G. Control of the acute phase response. Demonstrations of $\mathrm{C}$ reactive protein synthesis and secretion by hepatocytes during acute inflammation in the rabbit. J Exp Med 1978;148:466-77.

10 Oliveira EB, Gotschlich EC, Liu T. Primary structure of human C reactive protein. Proc Natl Acad Sci USA 1977;74:3148-51.

11 Sherlock S. The liver in heart failure. Relation of anatomical, functional, and circulatory changes. Br Heart J 1951; 13:273-93.

12 Myres JD, Hickman JB. Estimation of hepatic blood flow and splanchnic oxygen consumption in heart failure. and splanchnic oxygen cons

13 Cohen JA, Kaplan MM. Left side heart failure presenting hepatitis. Gastroenterology 1978;74:583-7.

14 Richman SM, Delman AJ, Grob D. Alterations in indices of liver function in congestive heart failure with particular reference to serum enzymes. Am J Med 1961;30:211-25. 